Article

\title{
Crystal Structure of 2-Ethylimidazole-1-sulfonyl Azide: A New Azidation Reagent
}

\section{Gerhard Laus ${ }^{1}$, Verena Adamer ${ }^{1}$, Michael Hummel ${ }^{1}$, Volker Kahlenberg ${ }^{2}$, Klaus Wurst ${ }^{1}$, Sven Nerdinger ${ }^{3}$ and Herwig Schottenberger ${ }^{1, *}$}

1 Faculty of Chemistry and Pharmacy, University of Innsbruck, 6020 Innsbruck, Austria

2 Institute of Mineralogy and Petrography, University of Innsbruck, 6020 Innsbruck, Austria

3 Sandoz GmbH, 6250 Kundl, Austria

* Author to whom correspondence should be addressed; E-Mail: herwig.schottenberger@uibk.ac.at; Tel.: +43-512-5120; Fax: +43-512-2934.

Received: 4 January 2012; in revised form: 21 February 2012 / Accepted: 29 February 2012 / Published: 12 March 2012

\begin{abstract}
Crystalline 2-ethylimidazole-1-sulfonyl azide was designed as a convenient reagent with improved thermal stability for electrophilic azidation of carbanions. The compound crystallized in the monoclinic space group $P 2_{1} / c$. The molecules are arranged into chains by short $\mathrm{C}-\mathrm{H} \cdots \mathrm{O}$ contacts along a two-fold screw axis. The quaternary 1-azidosulfonyl-2-ethyl-3-methylimidazolium tetrafluoroborate crystallized in $F d d 2$ with two independent ion pairs which engage in $\mathrm{C}-\mathrm{H} \cdots \mathrm{F}$ interactions.
\end{abstract}

Keywords: azide; electrophilic azidation; imidazole; stability

\section{Introduction}

Azides are versatile building blocks which play an important role in synthetic chemistry [1,2]. They can be used in "click chemistry" [3-6] to introduce heterocyclic structures and serve as a latent amino group [7]. However, most of the reagents commonly used to procure the azides, such as tosyl [8,9], triflyl [10-12], mesyl [13], or trisyl azide [14] suffer from hazardous properties and poor shelf life due to thermal instability [15]. Thus a robust and safe alternative is required. Recently, imidazole-1-sulfonyl azide hydrochloride was introduced as a new efficient and inexpensive diazo-transfer reagent [16]. Depending on the conditions, diazo-transfer reagents can also act as reagents for electrophilic azidation of carbanions [17-21]. Here we present the crystalline 
2-ethylimidazole-1-sulfonyl azide which we designed to offer several advantages over existing reagents regarding solubility and stability.

\section{Results and Discussion}

\subsection{Design and Synthesis}

The imidazole-1-sulfonyl group is an electron-withdrawing group which is able to replace the arenesulfonyl moieties. The capacity of an imidazole-1-sulfinate as an excellent leaving group resembles that of a benzenesulfinate. Hence, for the intended design of a new azidation reagent, the recently proposed imidazole-1-sulfonyl azide is a good option to start with. Notably, the solubility of imidazole in acid allows an alternative work-up procedure, thus expanding the methodological repertory. There are, however, several points still on a synthetic chemist's wish list, and the nature of the imidazole-based reagent leaves room for further development. We planned to address the following issues:

a) the solid hydrochloride is clearly not suitable for use with lithiated species, a free base is desired

b) imidazole-1-sulfonyl azide is liquid, but a solid is preferred for improved handling

c) the acidic 2-position of the imidazole should be blocked to facilitate its use with strong bases

d) solubility of the reagent in aprotic solvents is requested

Introduction of a 2-alkyl substituent was expected to raise the melting point and suitably protect the 2-position, thus killing two birds with one stone. In addition, the free base was assumed to exhibit sufficient solubility. According to this concept, the 2-methyl derivative was prepared but was found to be unsatisfactory due to its still low melting point and remaining acidity. Finally, our efforts settled on the 2-ethyl homologue which met all of the above requirements. The synthesis of 2-ethylimidazole-1sulfonyl azide (1) was accomplished by analogy with the reported procedure for imidazole-1-sulfonyl azide [16] with minor adaptations.

The quaternary 3-methyl and 3-ethylimidazolium tetrafluoroborates were also prepared in order to assess a modified leaving group. The crystal structure of the 3-methyl derivative $\mathbf{2}$ was determined. Furthermore, metathesis yielded the respective bis(trifluoromethyl-sulfonyl)imide ("triflimide") salts with increased solubility in less polar solvents. On the downside, triflimides often have very low melting points, rendering them liquid at room temperature ("ionic liquids" [22]). However, these tailormade derivatives did not show any additional advantages in preliminary experiments.

After completion of this exploratory work [23], another azole-1-sulfonyl azide was reported as diazo-transfer reagent [24] which also combined the above mentioned advantageous properties, confirming that our original considerations had been in the right direction.

\subsection{Crystal Structures of $\mathbf{1}$ and $\mathbf{2}$}

The title compound 1 crystallized in the monoclinic space group $P 2_{1} / c$. The asymmetric unit is shown in Figure 1a. The azide group is bent, and the N-N-N angle exhibits a typical value of $173.4^{\circ}$. The N3-N4 and N4-N5 bond lengths (1.272(3) and 1.111(3) A, respectively) are both comparable with those in other sulfonyl azides [24-27]. In arenesulfonyl azides, the $\mathrm{C}-\mathrm{S}$ and $\mathrm{S}-\mathrm{N}$ distances are 
reportedly sensitive to the electron-withdrawing power of the arene [25]. Here, the corresponding N1-S and S-N3 bonds are comparatively short with 1.654(2) and 1.657(2) A, which should not be over-interpreted since for obvious reasons $C$-sulfonyl and $N$-sulfonyl groups are sufficiently different to preclude such conclusions, but these bonds are also shorter than in the closely related benzotriazole compound (1.673(2) and 1.665(2) $\AA$ ) [24]. It is also noteworthy that the wave number of the infrared asymmetric $\mathrm{N}_{3}$ stretching vibration is significantly higher than in related compounds [25].

One $\mathrm{S}=\mathrm{O}$ bond resides near the plane of the imidazole ring (interplanar angle between ring and $\mathrm{N} 1-\mathrm{S} 1-\mathrm{O} 2$ plane $11.8^{\circ}$ ), the other one is rotated out of this plane by $37.0^{\circ}$. The almost perpendicular orientation of the $\mathrm{S}-\mathrm{N} 3$ unit with regard to the heterocycle, as judged by the dihedral angle of $73.8^{\circ}$ between the N1-S1-N3 plane and ring, is in line with other sulfonyl azides where the corresponding angles range from 60 to $88^{\circ}$. This is in stark contrast to the situation in benzoyl azides which exhibit a planar arrangement of the phenyl and the azidocarbonyl moieties [28]. The ethyl substituent lies almost perfectly within the ring plane (C5 tilted by only $1.6^{\circ}$ ).

A weak $\mathrm{C} 4-\mathrm{H} \cdots \mathrm{O} 2^{\mathrm{i}}$ interaction $(\mathrm{H} \cdots \mathrm{O} 2$ distance $2.54 \AA$, $\mathrm{C} 4 \cdots \mathrm{O} 2$ distance $3.424 \AA$, $\mathrm{C} 4 \cdots \mathrm{H} \cdots \mathrm{O} 2$ angle $149^{\circ}$; symmetry code $\mathrm{i}: 1-x,-1 / 2+y, 3 / 2-z$ ) is observed linking the molecules into infinite chains along a two-fold screw axis in the $\left[\begin{array}{lll}0 & 1 & 0\end{array}\right]$ direction (Figure 2).

Figure 1. (a) View of the 2-ethylimidazole-1-sulfonyl azide (1) molecule and (b) of the 1-azidosulfonyl-3-methyl-2-ethylimidazolium cation in $\mathbf{2}$, showing the atom-labeling scheme. The most notable difference is the orientation of the 2-ethyl group.

(a)

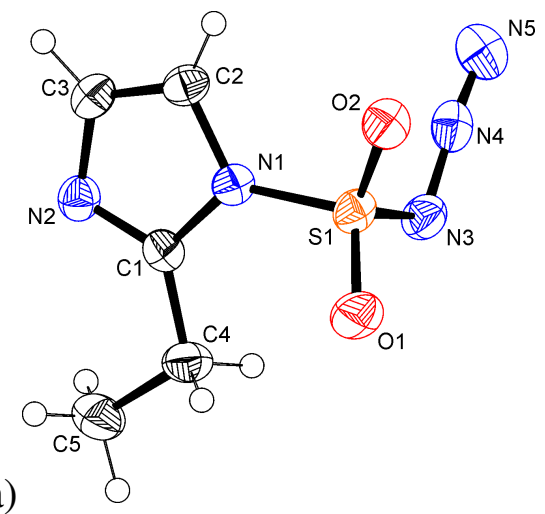

(b)

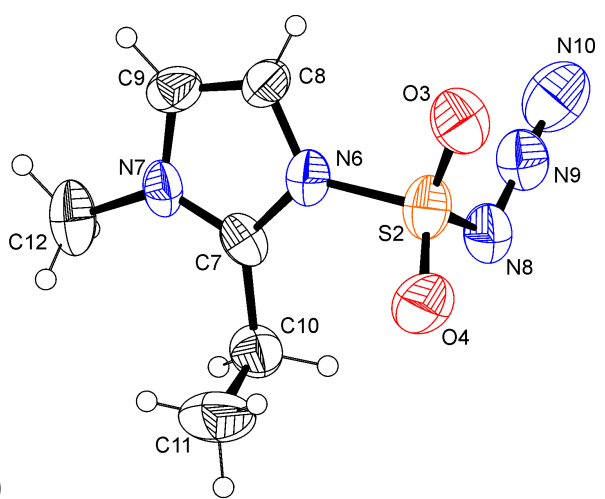

Figure 2. The molecules of $\mathbf{1}$ are arranged into chains by short $\mathrm{C}-\mathrm{H} \cdots \mathrm{O}$ contacts in the direction of the crystallographic $b$ axis.

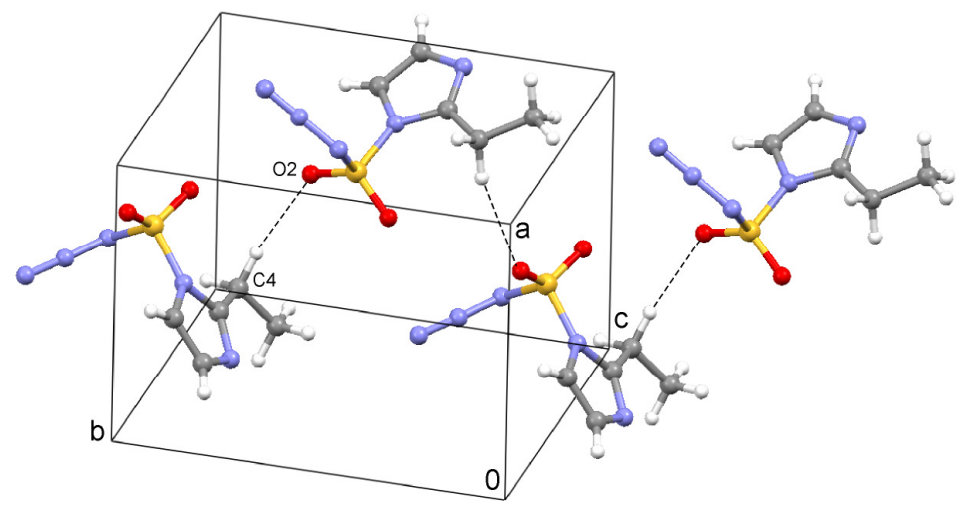


The asymmetric unit of the quaternary salt $\mathbf{2}$ contained two independent cations. Azide angles and $\mathrm{N}-\mathrm{N}$ bond lengths are not unusual. Again, one $\mathrm{S}=\mathrm{O}$ bond is located near the ring plane (tilted by only 5.6 and $6.4^{\circ}$ ), whereas the second one is rotated out of this plane by 45.0 and $41.0^{\circ}$, respectively. The orientation of the S-N3(8) unit resembles that of the free base 1, with interplanar angles of 66.0 and $65.3^{\circ}$. In a remarkable conformational difference between the two structures (Figure 1a,b), the ethyl substituent in $\mathbf{2}$ is oriented almost perpendicular to the ring plane $\left(87.4\right.$ and $\left.89.7^{\circ}\right)$. The tetrafluoroborate ions exhibit distorted tetrahedral geometries ( $\mathrm{F}-\mathrm{B}-\mathrm{F}$ angles range from 103 to $\left.119^{\circ}\right)$. One $\mathrm{BF}_{4}$ anion, on a general position, is disordered with a refined ratio of 2:1 for the fluorine atoms. The boron atoms of the other anions, B2 and B3, lie on a twofold rotation axis with direction [ $\left[\begin{array}{lll}0 & 0 & 1\end{array}\right]$. Several significant interactions between the hydrogen atoms of the cations and fluorine atoms of the anions can be recognized (Figure 3). The detailed parameters of these contacts are summarized in Table 1.

Figure 3. The components of 2 engage in short interionic $\mathrm{C}-\mathrm{H} \cdots \mathrm{F}$ contacts.

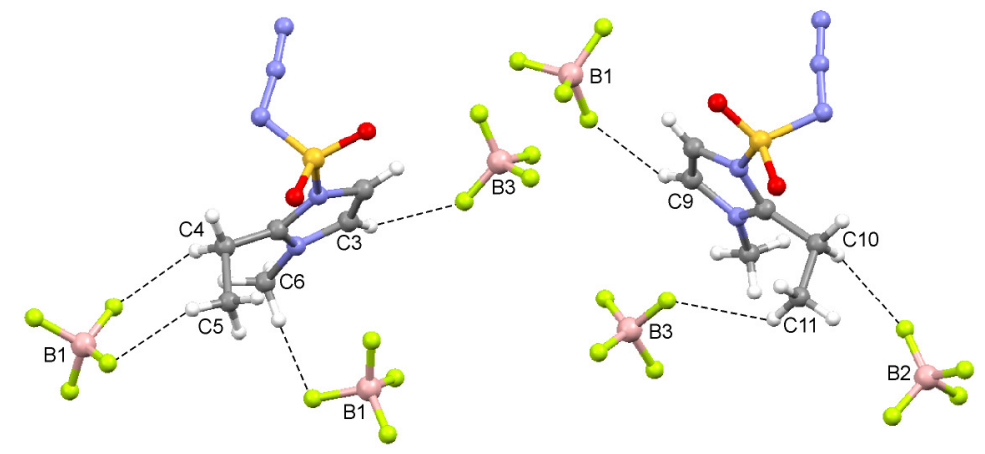

Table 1. Distances and angles for the short $\mathrm{C}-\mathrm{H} \cdots \mathrm{F}$ contacts $\left(\AA^{\circ},{ }^{\circ}\right)$ in the structure of 2.

\begin{tabular}{lllll}
\hline Interaction & $\mathrm{H} \cdots \mathrm{F}$ & $\mathrm{C} \cdots \mathrm{F}$ & $\mathrm{C}-\mathrm{H} \cdots \mathrm{F}$ & Symmetry code $(\mathrm{F})$ \\
\hline $\mathrm{C} 3-\mathrm{H} \cdots \mathrm{F}$ & $2.399(8)$ & $3.14(1)$ & $135.3(6)$ & $x,-1 / 2+y,-1 / 2+z$ \\
$\mathrm{C} 4-\mathrm{H} \cdots \mathrm{F}$ & $2.56(2)$ & $3.44(2)$ & $148.9(6)$ & $-1 / 4+x,-1 / 4-y,-3 / 4+z$ \\
$\mathrm{C} 5-\mathrm{H} \cdots \mathrm{F}$ & $2.57(2)$ & $3.26(2)$ & $128.3(8)$ & $-1 / 4+x,-1 / 4-y,-3 / 4+z$ \\
$\mathrm{C} 6-\mathrm{H} \cdots \mathrm{F}$ & $2.29(1)$ & $3.19(1)$ & $155.3(7)$ & $1 / 4-x,-1 / 4+y,-1 / 4+z$ \\
$\mathrm{C} 9-\mathrm{H} \cdots \mathrm{F}$ & $2.47(2)$ & $3.29(2)$ & $146.0(7)$ & - \\
$\mathrm{C} 10-\mathrm{H} \cdots \mathrm{F}$ & $2.404(8)$ & $3.14(1)$ & $131.3(6)$ & $1 / 4-x,-1 / 4+y, 3 / 4+z$ \\
$\mathrm{C} 11-\mathrm{H} \cdots \mathrm{F}$ & $2.57(1)$ & $3.22(2)$ & $124.3(7)$ & $1 / 4-x,-1 / 4+y,-1 / 4+z$ \\
\hline
\end{tabular}

\subsection{Reactivity and Stability}

We investigated the title compound and some derivatives as potential reagents for electrophilic azidation of carbanions. Ferrocene and 4-methoxybiphenyl served as model substrates. Lithiation (tert-BuLi [29] and $n$-BuLi [30], respectively) followed by addition of $\mathbf{1}$ and purification by chromatography yielded known 1-azidoferrocene [31] and new 3-azido-4-methoxybiphenyl, providing proof of principle that $\mathbf{1}$ can act as an azidation reagent [23]. The other reagents, 3-methyl and 3-ethylimidazolium salts $\mathbf{2}, \mathbf{2 a}, \mathbf{3}$ and $\mathbf{3 a}$, gave similar, but not superior, results. 
Most diazo-transfer or azidation reagents suffer from poor thermal stability [15]. DSC analysis of $\mathbf{1}$ showed decomposition at $157{ }^{\circ} \mathrm{C}$ with an onset temperature of $142{ }^{\circ} \mathrm{C}$; the quaternary salt 2 decomposed at $187^{\circ} \mathrm{C}$ (Figure 3). Inherently, no azide can be considered completely innocent, but the new reagents are among the safest.

Figure 3. Differential Scanning Calorimetry (DSC) curves of 1 (blue) and 2 (green) showing the endothermic melting events and the exothermic decomposition.

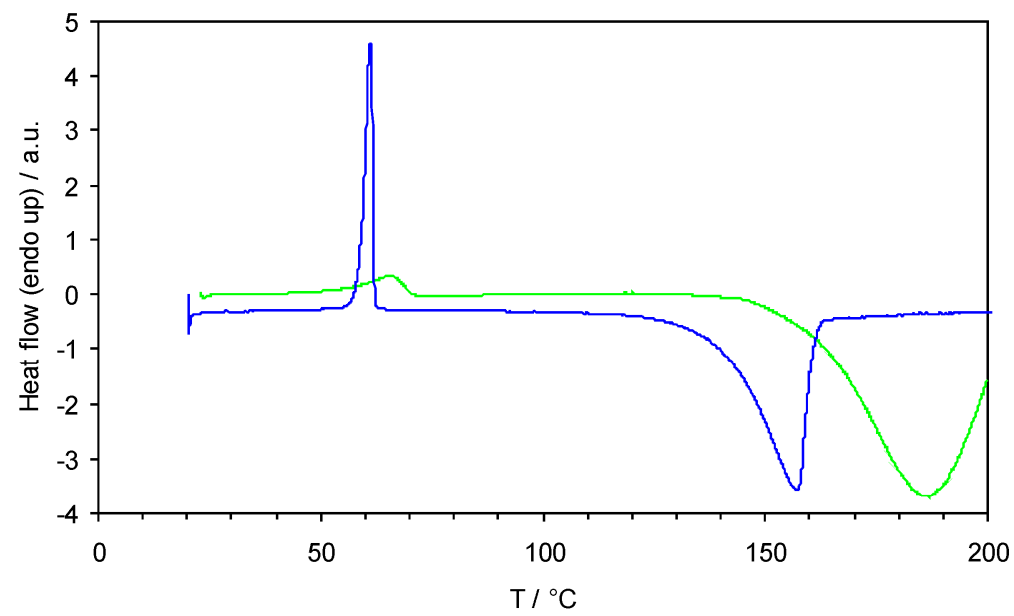

\section{Experimental Section}

\subsection{Synthesis of 2-Ethylimidazole-1-sulfonyl Azide (1)}

Cautionary note: although we did not encounter any difficulties, azides should generally be treated with respect because they are potentially explosive. $\mathrm{SO}_{2} \mathrm{Cl}_{2}(8.1 \mathrm{~mL}, 0.1 \mathrm{~mol})$ was added within 10 min to $\mathrm{NaN}_{3}(6.5 \mathrm{~g}, 0.1 \mathrm{~mol})$ in anhydrous $\mathrm{CH}_{3} \mathrm{CN}(100 \mathrm{~mL})$ at $0{ }^{\circ} \mathrm{C}$, and the suspension was stirred for $26 \mathrm{~h}$ at room temperature. 2-Ethylimidazole $(19.2 \mathrm{~g}, 0.2 \mathrm{~mol})$ was added and stirring continued at room temperature for $3 \mathrm{~h}$. Longer reaction times gave lower yields. The mixture was partitioned between EtOAc $(200 \mathrm{~mL})$ and $\mathrm{H}_{2} \mathrm{O}(100 \mathrm{~mL})$, the organic phase was washed with $\mathrm{H}_{2} \mathrm{O}(200 \mathrm{~mL})$ and saturated $\mathrm{NaHCO}_{3}$ solution $(2 \times 100 \mathrm{~mL})$, dried over anhydrous $\mathrm{MgSO}_{4}$, and the solvent evaporated. The resulting crude solid was stirred in $\mathrm{Et}_{2} \mathrm{O}(15 \mathrm{~mL})$ at $40{ }^{\circ} \mathrm{C}$, and a small amount of insoluble brown oil was removed by filtration. A seed crystal of the crude product was added to the ice-cooled filtrate, immediate crystallization occurred, and the colourless crystalline product was collected, washed with cold $\mathrm{Et}_{2} \mathrm{O}(5 \mathrm{~mL})$ and iso-pentane $(20 \mathrm{~mL})$, and vacuum-dried (yield 8.9 g, $44 \%$ ). m.p. $61{ }^{\circ} \mathrm{C} .{ }^{1} \mathrm{H}$ NMR ( $\left.\mathrm{CDCl}_{3}, 300 \mathrm{MHz}\right): \delta 1.36(\mathrm{t}, J=7.4 \mathrm{~Hz}, 3 \mathrm{H}), 2.94(\mathrm{q}, J=7.4 \mathrm{~Hz}, 2 \mathrm{H}), 6.97(\mathrm{~d}, J=1.8 \mathrm{~Hz}, 1 \mathrm{H})$, $7.31(\mathrm{~d}, J=1.8 \mathrm{~Hz}, 1 \mathrm{H}) \mathrm{ppm} .{ }^{13} \mathrm{C} \mathrm{NMR}\left(\mathrm{CDCl}_{3}, 75 \mathrm{MHz}\right): \delta 11.7,22.2,119.8,128.7,151.4 \mathrm{ppm}$. IR (neat): v $3136(\mathrm{w}), 3115(\mathrm{~m}), 2981(\mathrm{w}), 2940(\mathrm{w}), 2157$ (s), $1547(\mathrm{~m}), 1435(\mathrm{~m}), 1408$ (s), 1189 (s), 1149 (s), 1124 (s), 1043 (s), 885 (m), 774 (s), 758 (s), 691 (m), 628 (s), 582 (s) cm cm $^{-1}$ 


\subsection{Synthesis of 1-Azidosulfonyl-3-alkyl-2-ethylimidazolium Tetrafluoroborates (2 and 3)}

A mixture of 2-ethylimidazole-1-sulfonyl azide $(1.0 \mathrm{~g}, 5 \mathrm{mmol})$ and trialkyloxonium (methyl for 2 , ethyl for 3 ) tetrafluoroborate $(5 \mathrm{mmol})$ in dry $\mathrm{CH}_{2} \mathrm{Cl}_{2}(10 \mathrm{~mL})$ was stirred for $48 \mathrm{~h}$ at room temperature. After removal of the solvent the remaining syrup crystallized after several days.

2: Single crystals were obtained by slow evaporation of a $\mathrm{CH}_{2} \mathrm{Cl}_{2}$ solution. m.p. $66{ }^{\circ} \mathrm{C} .{ }^{1} \mathrm{H}$ NMR (DMSO-d $\left.{ }_{6}, 300 \mathrm{MHz}\right): \delta 1.25(\mathrm{t}, J=7.6 \mathrm{~Hz}, 3 \mathrm{H}), 2.92(\mathrm{q}, J=7.6 \mathrm{~Hz}, 2 \mathrm{H}), 3.74(\mathrm{~s}, 3 \mathrm{H}), 7.54(\mathrm{~s}, 1 \mathrm{H})$, 5.56 (s, 1H) ppm. ${ }^{13} \mathrm{C}$ NMR (DMSO-d $\left.6,75 \mathrm{MHz}\right): \delta 10.5,17.7,33.9,117.9,123.2,148.4 \mathrm{ppm}$. IR (neat): $v 3147(\mathrm{w}), 2167(\mathrm{~m}), 1425(\mathrm{~m}), 1193(\mathrm{~m}), 1146(\mathrm{~m}), 1024(\mathrm{~s}), 773(\mathrm{~m}), 570(\mathrm{~s}) \mathrm{cm}^{-1}$.

3: ${ }^{1} \mathrm{H} \mathrm{NMR}\left(\mathrm{CDCl}_{3}, 300 \mathrm{MHz}\right): \delta 1.40(\mathrm{t}, J=7.7 \mathrm{~Hz}, 3 \mathrm{H}), 1.60(\mathrm{t}, J=7.4 \mathrm{~Hz}, 3 \mathrm{H}), 3.27(\mathrm{q}$, $J=7.7 \mathrm{~Hz}, 2 \mathrm{H}), 4.27(\mathrm{q}, J=7.4 \mathrm{~Hz}, 2 \mathrm{H}), 7.47(\mathrm{~d}, J=2.5 \mathrm{~Hz}, 1 \mathrm{H}), 7.68(\mathrm{~d}, J=2.5 \mathrm{~Hz}, 1 \mathrm{H}) \mathrm{ppm} .{ }^{13} \mathrm{C}$ NMR $\left(\mathrm{CDCl}_{3}, 75 \mathrm{MHz}\right): \delta 11.9,14.5,19.3,45.3,121.2,121.7,151.0 \mathrm{ppm}$.

\subsection{Synthesis of 1-Azidosulfonyl-3-alkyl-2-ethylimidazolium Triflimides (2a and 3a)}

A solution of Li triflimide $(2.01 \mathrm{~g}, 7 \mathrm{mmol})$ in $\mathrm{H}_{2} \mathrm{O}(3 \mathrm{~mL})$ was added to a stirred solution of the respective tetrafluoroborate $(7 \mathrm{mmol})$ in $\mathrm{H}_{2} \mathrm{O}(50 \mathrm{~mL})$. The mixture was extracted with $\mathrm{CH}_{2} \mathrm{Cl}_{2}$ $(2 \times 50 \mathrm{~mL})$. The organic phase was washed with $\mathrm{H}_{2} \mathrm{O}(2 \times 100 \mathrm{~mL})$, dried over anhydrous $\mathrm{Na}_{2} \mathrm{SO}_{4}$, and the solvent was evaporated. The resulting clear liquid was vacuum-dried.

2a: ${ }^{1} \mathrm{H} \mathrm{NMR}\left(\mathrm{CDCl}_{3}, 300 \mathrm{MHz}\right): \delta 1.39(\mathrm{t}, J=7.7 \mathrm{~Hz}, 3 \mathrm{H}), 3.27(\mathrm{q}, J=7.7 \mathrm{~Hz}, 2 \mathrm{H}), 3.96(\mathrm{~s}, 3 \mathrm{H})$, $7.41(\mathrm{~d}, J=2.4 \mathrm{~Hz}, 1 \mathrm{H}), 7.64(\mathrm{~d}, J=2.4 \mathrm{~Hz}, 1 \mathrm{H}) \mathrm{ppm} .{ }^{1} \mathrm{H}$ NMR $\left(\mathrm{DMSO}-\mathrm{d}_{6}, 300 \mathrm{MHz}\right): \delta 1.24(\mathrm{t}$, $J=7.6 \mathrm{~Hz}, 3 \mathrm{H}), 2.91(\mathrm{q}, J=7.6 \mathrm{~Hz}, 2 \mathrm{H}), 3.74(\mathrm{~s}, 3 \mathrm{H}), 7.52(\mathrm{~d}, J=1.8 \mathrm{~Hz}, 1 \mathrm{H}), 7.55(\mathrm{~d}, J=1.8 \mathrm{~Hz}, 1 \mathrm{H})$ ppm. ${ }^{13} \mathrm{C} \mathrm{NMR}\left(\mathrm{CDCl}_{3}, 75 \mathrm{MHz}\right): \delta 11.2,19.4,36.7,120.0(\mathrm{q}, J=321 \mathrm{~Hz}), 120.7,124.0,151.7 \mathrm{ppm}$.

3a: ${ }^{1} \mathrm{H}$ NMR (DMSO-d $\left.6,300 \mathrm{MHz}\right): \delta 1.26(\mathrm{t}, J=7.5 \mathrm{~Hz}, 3 \mathrm{H}), 1.35(\mathrm{t}, J=7.2 \mathrm{~Hz}, 3 \mathrm{H}), 2.95(\mathrm{q}$, $J=7.5 \mathrm{~Hz}, 2 \mathrm{H}), 4.11(\mathrm{q}, J=7.2 \mathrm{~Hz}, 2 \mathrm{H}), 7.59(\mathrm{~s}, 1 \mathrm{H}), 7.66(\mathrm{~s}, 1 \mathrm{H}) \mathrm{ppm} .{ }^{13} \mathrm{C}$ NMR (DMSO-d 6,75 $\mathrm{MHz}): \delta 11.0,15.1,17.6,42.0,118.3,120.0(\mathrm{q}, J=321 \mathrm{~Hz}), 121.4,147.8 \mathrm{ppm}$.

\subsection{Azidation of 4-Methoxybiphenyl}

A solution of 4-methoxybiphenyl $(500 \mathrm{mg}, 2.71 \mathrm{mmol})$ in dry THF $(15 \mathrm{~mL})$ was cooled to $-40{ }^{\circ} \mathrm{C}$ under argon. TMEDA $(310 \mathrm{mg}, 2.66 \mathrm{mmol})$ and $n$-BuLi $(1.6 \mathrm{M}$ solution in hexane, $1.70 \mathrm{~mL}$, $2.72 \mathrm{mmol}$ ) were added and the reaction mixture warmed to room temperature over a period of $2 \mathrm{~h}$. The slightly yellowish solution was cooled again $\left(-70{ }^{\circ} \mathrm{C}\right)$, and a solution of 2-ethylimidazole-1sulfonyl azide in THF $(5 \mathrm{~mL})$ was added. The mixture was stirred overnight at room temperature. After removal of the solvent, the residue was partitioned between $\mathrm{CH}_{2} \mathrm{Cl}_{2}$ and $\mathrm{H}_{2} \mathrm{O}$. The organic layer was washed with $\mathrm{H}_{2} \mathrm{O}$, dried over $\mathrm{Na}_{2} \mathrm{SO}_{4}$, and the solvent was evaporated. Chromatography (silica, $n$-hexane/EtOAc $=3: 1)$ of the crude product gave 3-azido-4-methoxybiphenyl as an oil $(120 \mathrm{mg}, 20 \%)$. ${ }^{1} \mathrm{H} \mathrm{NMR}\left(\mathrm{CDCl}_{3}, 300 \mathrm{MHz}\right): \delta 3.92(3 \mathrm{H}, \mathrm{s}), 6.96(1 \mathrm{H}, \mathrm{d}, J=8.5 \mathrm{~Hz}), 7.24(1 \mathrm{H}, \mathrm{d}, J=2.2 \mathrm{~Hz})$, 7.31-7.36 $(2 \mathrm{H}, \mathrm{m}), 7.43(2 \mathrm{H}, \mathrm{t}, J=8.0 \mathrm{~Hz}), 7.53(2 \mathrm{H}, \mathrm{d}, J=8.0 \mathrm{~Hz}) \mathrm{ppm} .{ }^{13} \mathrm{C} \mathrm{NMR}\left(\mathrm{CDCl}_{3}\right.$, $75 \mathrm{MHz}): \delta 56.3,112.6,119.3,124.5,126.9,127.0,127.5,129.1,135.0,140.2,151.7$ ppm. IR (neat): $v$ $2107 \mathrm{~cm}^{-1}$. 


\subsection{X-ray Data Collection and Structure Refinement}

Structure solution and refinement was performed with the programs SIR2002 (direct methods) [32] and SHELXL-97 [33].

1: Stoe IPDS-II diffractometer, Mo-K $\alpha$ radiation; rotation method; $T=173(2) \mathrm{K} ; \theta_{\max }=25.7^{\circ}$; indices: $-9 \leq h \leq 9,-12 \leq k \leq 12,-12 \leq l \leq 12 ; D_{\mathrm{x}}=1.56 \mathrm{~g} \mathrm{~cm}^{-3} ; 4991$ reflections measured, 1562 independent with $R_{\text {int }}=0.050, F(000)=416, \mu=0.35 \mathrm{~mm}^{-1}$. Crystal data for $\mathrm{C}_{5} \mathrm{H}_{7} \mathrm{~N}_{5} \mathrm{O}_{2} \mathrm{~S}$ $\left(M=201.22 \mathrm{~g} \mathrm{~mol}^{-1}\right)$. Monoclinic, $P 2{ }_{1} / c, a=8.0815(7), b=10.0732(9), c=10.7291(10) \AA$, $\beta=100.383(7)^{\circ}, V=859.11(13) \AA^{3}, Z=4 . R_{1}=0.038$ and $w R_{2}=0.089$ for 1211 reflections with $I>2 \sigma(I), R_{1}=0.054$ and $w R_{2}=0.094$ for all data; $S=1.00 ; \Delta \rho_{\max }=0.27$ and $\Delta \rho_{\min }=-0.32 \mathrm{e} \AA^{-3}$. CCDC reference number: 853383 .

2: Nonius KappaCCD diffractometer, Mo-K $\alpha$ radiation; $\varphi$ and $\omega$ scans; $T=233(2) \mathrm{K} ; \theta_{\max }=21.0^{\circ}$; indices: $-24 \leq h \leq 24,-29 \leq k \leq 30,-13 \leq l \leq 13 ; D_{\mathrm{x}}=1.60 \mathrm{~g} \mathrm{~cm}^{-3} ; 9666$ reflections measured, 2699 independent with $R_{\text {int }}=0.073, F(000)=4928, \mu=0.31 \mathrm{~mm}^{-1}$. Crystal data for $\mathrm{C}_{6} \mathrm{H}_{10} \mathrm{BF}_{4} \mathrm{~N}_{5} \mathrm{O}_{2} \mathrm{~S}$ $\left(M=303.06 \mathrm{~g} \mathrm{~mol}^{-1}\right)$. Orthorhombic, $F d d 2, a=24.375(1), b=30.163(2), c=13.653(1) \AA$, $V=10038.0(11) \AA^{3}, Z=32 . R_{1}=0.054$ and $w R_{2}=0.132$ for 2010 reflections with $I>2 \sigma(I), R_{1}=0.082$ and $w R_{2}=0.147$ for all data; $S=1.04 ; \Delta \rho_{\max }=0.24$ and $\Delta \rho_{\min }=-0.21$ e $\AA^{-3}$. CCDC reference number: 855784. These data can be obtained free of charge from The Cambridge Crystallographic Data Centre.

\section{Conclusions}

There is continued interest in the exploration of inexpensive azidation reagents. They are important tools for $\mathrm{C}-\mathrm{N}$ bond formation which is a topic of high relevance in synthetic chemistry. The new reagent presented in this work showed promising reactivity. The quaternary salts were disappointing as they did not exhibit the superior properties we had hoped. The two crystal structures, however, contribute valuable data to the still scarce knowledge of this class of compounds.

\section{Acknowledgments}

Financial support of this work by Sandoz GmbH is gratefully acknowledged.

\section{References and Notes}

1. Bräse, S.; Gil, C.; Knepper, K.; Zimmermann, V. Organic Azides: An Exploding Diversity of a Unique Class of Compounds. Angew. Chem. Int. Ed. 2005, 44, 5188-5240.

2. Scriven, E.F.V.; Turnbull, K. Azides: Their Preparation and Synthetic Uses. Chem. Rev. 1988, 88, 297-368.

3. Kolb, H.C.; Finn, M.G.; Sharpless, K.B. Click Chemistry: Diverse Chemical Function from a Few Good Reactions. Angew. Chem. Int. Ed. 2001, 40, 2004-2021.

4. Rostovtsev, V.V.; Green, L.G.; Fokin, V.V.; Sharpless, K.B. A Stepwise Huisgen Cycloaddition Process: Copper(I)-Catalyzed Regioselective Ligation of Azides and Terminal Alkynes. Angew. Chem. Int. Ed. 2002, 41, 2596-2599.

5. Bock, V.D.; Hiemstra, H.; van Maarseveen, J.H. Cu-Catalyzed Alkyne-Azide "Click" Cycloadditions from a Mechanistic and Synthetic Perspective. Eur. J. Org. Chem. 2006, 51-68. 
6. Amblard, F.; Cho, J.H.; Schinazi, R.F. Cu(I)-Catalyzed Huisgen Azide-Alkyne 1,3-Dipolar Cycloaddition Reaction in Nucleoside, Nucleotide, and Oligonucleotide Chemistry. Chem. Rev. 2009, 109, 4207-4220.

7. Nyffeler, P.T.; Liang, C.-H.; Koeller, K.M.; Wong, C.-H. The Chemistry of Amine-Azide Interconversion: Catalytic Diazotransfer and Regioselective Azide Reduction. J. Am. Chem. Soc. 2002, 124, 10773-10778.

8. Regitz, M. New Methods of Preparative Organic Chemistry. Transfer of Diazo Groups. Angew. Chem. Int. Ed. Engl. 1967, 6, 733-749.

9. Curphey, T.J. Preparation of $p$-toluenesulfonyl azide. A cautionary note. Org. Prep. Proc. Int. 1981, 13, 112-115.

10. Cavender, C.J.; Shiner, V.J., Jr. Trifluoromethanesulfonyl Azide. Its Reaction with Alkyl Amines to Form Alkyl Azides. J. Org. Chem. 1972, 37, 3567-3569.

11. Liu, Q.; Tor, Y. Simple Conversion of Aromatic Amines into Azides. Org. Lett. 2003, 14, 2571-2572.

12. Zaloom, J.; Roberts, D.C. Preparation of Azido Derivatives from Amino Acids and Peptides by Diazo Transfer. J. Org. Chem. 1981, 46, 5173-5176.

13. Taber, D.F.; Ruckle, R.E.; Hennessy, M.J. Mesyl Azide: A Superior Reagent for Diazo Transfer. $J$. Org. Chem. 1986, 51, 4077-4078.

14. Besenyei, G.; Parkanyi, L.; Foch, I.; Simandi, L.I. Sterically controlled pathways in the reaction of 2,4,6-tris(isopropyl)benzenesulfonyl azide and $\left.\left[\mathrm{Pd}_{2} \mathrm{Cl}_{2} \text { (dppm) }\right)_{2}\right]$. Angew. Chem. Int. Ed. 2000, 39, 956-958.

15. Tuma, L.D. Identification of a safe diazotransfer reagent. Thermochim. Acta 1994, 243, 161-167.

16. Goddard-Borger, E.D.; Stick, R.V. An Efficient, Inexpensive, and Shelf-Stable Diazotransfer Reagent: Imidazole-1-sulfonyl Azide Hydrochloride. Org. Lett. 2007, 9, 3797-3800 and Supporting Information.

17. Benati, L.; Nanni, D.; Spagnolo, P. Reactions of Benzocyclic $\beta$-Keto Esters with Sulfonyl Azides. Further Insight into the Influence of Azide Structure and Solvent on the Reaction Course. J. Org. Chem. 1999, 64, 5132-5138.

18. Kumar, J.S.D.; Dupradeau, F.-Y.; Strouse, M.J.; Phelps, M.E.; Toyokuni, T. Electrophilic Azidation for Stereoselective Synthesis of 2-Azido-2-deoxyaldono-1,5-lactones. J. Org. Chem. 2001, 66, 3220-3223.

19. Batch, A.; Dodd, R.H. Ortho-Directed Metalation of 3-Carboxy- $\beta$-carbolines: Use of the $\mathrm{SmI}_{2}-$ Cleavable 9-N-(N',N'-Dimethylsulfamoyl) Blocking Group for the Preparation of 9-N-Deprotected 4-Amino Derivatives via Azide Introduction or a Palladium-Catalyzed Cross-Coupling Reaction. $J$. Org. Chem. 1998, 63, 872-877.

20. Hanessian, S.; Bennani, Y.L. Electrophilic Amination and Azidation of Chiral $\alpha$-Alkyl Phosphonamides: Asymmetric Syntheses of $\alpha$-Amino $\alpha$-Alkyl Phosphonic Acids. Synthesis 1994, 1272-1274.

21. Denmark, S.E.; Chatani, N.; Pansare, S.V. Asymmetric electrophilic amination of chiral phosphorus-stabilized anions. Tetrahedron 1992, 48, 2191-2208. 
22. Ionic Liquids in Synthesis, 2nd ed.; Wasserscheid, P., Welton, T., Eds.; Wiley-VCH: Weinheim, Germany, 2007.

23. Laus, G.; Hummel, M.; Adamer, V.; Bentivoglio, G.; Wurst, K.; Griesser, U.; Schottenberger, H. Approaches to Azidometallocenes and Related Azidoarenes. In Proceedings of 7th Ferrocene Colloquium, Düsseldorf, Germany, 2009.

24. Katritzky, A.R.; El Khatib, M.; Bol'shakov, O.; Khelashvili, L.; Steel, P.J. Benzotriazol-1-ylsulfonyl Azide for Diazotransfer and Preparation of Azidoacylbenzotriazoles. J. Org. Chem. 2010, 75, 6532-6539.

25. Besenyei, G.; Parkanyi, L.; Foch, I.; Simandi, L.I.; Kalman, A. Crystallographic characterisation of arenesulfonyl azides. Structural and kinetic effects induced by ortho- and para-substituents. $J$. Chem. Soc. Perkin Trans. 2 2000, 1798-1802.

26. Vicarel, M.L.; Norris, P.; Zeller, M. 4-Acetamidobenzenesulfonyl azide. Acta Crystallogr. 2006, E62, o1751-o1753.

27. Basanagouda, M.; Nayak, S.K.; Row, T.N.G.; Kulkarni, M.V. 4-Azidomethyl-7-methyl-2-oxo-2Hchromene-6-sulfonyl azide. Acta Crystallogr. 2010, E66, o2780.

28. Parkanyi, L.; Besenyei, G. Crystallographic characterisation of benzoyl azides. A comparative study. J. Mol. Struct. 2004, 691, 97-106.

29. Herberhold, M.; Ayazi, A.; Milius, W.; Wrackmeyer, B. Silyl derivatives of ferrocene with pending indenyl or fluorenyl substituents at silicon. J. Organomet. Chem. 2002, 656, 71-80.

30. Trost, B.M.; Pearson, W.H. Azidomethyl Phenyl Sulfide. A Synthon for $\mathrm{NH}_{2}{ }^{+}$. J. Am. Chem. Soc. 1981, 103, 2483-2485.

31. Walla, P.; Arion, V.B.; Brinker, U.H. Solvent- and Temperature-Tuned Orientation of Ferrocenyl Azide Inside $\beta$-Cyclodextrin. J. Org. Chem. 2006, 71, 3274-3277.

32. Burla, M.C.; Carrozzini, B.; Cascarano, G.L.; Giacovazzo, C.; Polidori, G. More power for direct methods: SIR2002. Z. Kristallogr. 2002, 217, 629-635.

33. Sheldrick, G.M. A short history of SHELX. Acta Crystallogr. 2008, A64, 112-122.

(C) 2012 by the authors; licensee MDPI, Basel, Switzerland. This article is an open access article distributed under the terms and conditions of the Creative Commons Attribution license (http://creativecommons.org/licenses/by/3.0/). 